\title{
(ब) A $A$ condição humana e a condição docente: das ilusões de onipotência ao reconhecimento do desamparo
}

Resumo: Partindo do princípio de que todo processo educacional é aberta ou veladamente guiado por uma determinada maneira de se compreender o ser humano, procuramos nesse artigo colocar em questão os ideais de "humano", e consequentemente, de humano-professor, que a tradição ocidental nos legou. Em seguida, tentamos indicar alguns caminhos para repensarmos contemporaneamente o que significa ser humano e, por conseguinte, o que significa ser professor. Enquanto os antigos ideais insistem em projeções de poder e invulnerabilidade ao assumir uma essência imaterial para o humano, apostamos numa concepção de humano encarnado, afetivo e desejante que envolve, em contrapartida, a disposição para assumirmos o irremediável desamparo e a incontornável vulnerabilidade que são intrínsecos à condição humana.

Palavras-chave: condição humana; ilusões de onipotência; desamparo

The human condition and the teacher condition: from the illusions of omnipotence to the recognition of helplessness

\begin{abstract}
Assuming that every educational process is openly or veiled guided by a certain way of understanding the human being, we seek in this article to question the ideals of "human," and consequently of human-teacher, that the Western tradition bequeathed to us. Next, we try to indicate some ways to rethink contemporaneously what it means to be human and, therefore, what it means to be
\end{abstract}

\footnotetext{
* Doutor em Filosofia pela Pontifícia Universidade Católica (PUC-RIO). Professor Assistente de Filosofia Política da Educação no Departamento de Estudos da Subjetividade e da Formação Humana na Faculdade de Educação da Universidade Estadual do Rio de Janeiro (UERJ). E-mail: diogobogeaa@hotmail.com ORCID: https://orcid.org/00000001-5862-819X
} 
a teacher. While the old ideals insist on projections of power and invulnerability by assuming an immaterial essence for the human, we bet on an incarnate, affective and desiring human conception that involves, on the other hand, the disposition to assume the irremediable helplessness and the unavoidable vulnerability that are intrinsic to the human condition.

Keywords: human condition; omnipotence illusions; helplessness

\section{La condición humana y la condición docente: de las ilusiones de omnipotencia al reconocimiento del desamparo}

Resumen: A partir del principio de que todo proceso educativo es abierto o veladamente guiado por una determinada manera de comprenderse el ser humano, buscamos en ese artículo plantear en cuestión los ideales de "humano", y consecuentemente, de humano-profesor, que la tradición occidental en legó. A continuación, intentamos indicar algunos caminos para repensar contemporáneamente lo que significa ser humano y, por lo tanto, lo que significa ser profesor. Mientras los antiguos ideales insisten en proyecciones de poder e invulnerabilidad al asumir una esencia inmaterial para lo humano, apostamos en una concepción de humano encarnado, afectivo y deseante que envuelve, en contrapartida, la disposición para asumir el irremediable desamparo y la ineludible vulnerabilidad que son intrínsecos a la condición humana.

Palabras clave: condición humana; ilusiones de omnipotencia; desamparo

Era uma tarde fria de outono em Teresópolis; uma daquelas em que "o ruço desce", por volta das três horas. O cenário: um corredor. O corredor do Colégio Estadual Presidente Bernardes, municipalizado às pressas para receber os alunos que não eram mais bem-vindos em nenhuma outra Escola do município. Alunos repetidamente expulsos de outras escolas, alunos com laudos psiquiátricos, alunos com históricos recheados de graves episódios de indisciplina e violência. A largura de uma Escola comprimida naquele estreito claustro tornava aquele corredor sufocante. $\mathrm{O}$ comprimento daquele corredor variava indefinidamente. Cada 
caminhada em direção à próxima sala parecia uma pequena eternidade angustiante, um eterno milissegundo de ansiedade que tentava, em vão, me preparar para o "trauma" da próxima aula. Naquela tarde fria de outono, eu caminhava decidido e trêmulo, em direção à 601. A compressão dolorida no peito, que já há meses me acompanhava, dava sinais de um leve agravamento. Antes do último passo, parar, respirar fundo, endurecer o espírito. Mais um passo, chego à porta aberta. Paro novamente. A perplexidade suspende minha presença autoconsciente e sou invadido pelo terror. Estou diante do caos. No fundo esquerdo da sala, um grupo de 5 garotos troca socos e pontapés. Os garotos ainda estão decidindo sobre o que efetivamente fazem, se brincando ou brigando. Mais para o meio, ainda no canto esquerdo, um grupo se diverte derramando liquid paper em bolinhas de papel e atirando as desajeitadas granadas de tinta branca uns sobre os outros. Os gritos se sobrepõem confusamente. Agressões físicas e verbais circulam por todos os cantos da sala. Desisto de entrar. Mais dois passos e estou na sala da direção, que encabeça o corredor. A diretora de primeira viagem, apadrinhada pelo prefeito, diz que tenho de entrar. Diz que tenho de ser eu o deus ex machina a criar a ordem a partir do caos. Diz que tenho que ter "domínio de turma", "pulso firme" e que não mande alunos para a direção, nem para fora de sala. Tenho que "me virar".

Foi assim aquele ano de 2013. De segunda a sexta, oito turmas de sexto ano de comunidades em situação de vulnerabilidade socioeconômica. Ninguém será capaz de me convencer que, enquanto professor, estive a serviço de algum projeto macropolítico: em nenhum momento, entre um passo e outro naquele estreito corredor, eu me senti um agente a serviço da classe dominante, um veículo de reprodução e perpetuação dos valores sociais dominantes; mas tampouco me senti como um agente transformador da sociedade. Era muito claro para mim que minhas aulas não resultariam em nenhuma revolução macropolítica. Seria também incapaz de dizer em que medida minhas aulas eram "tradicionais" ou "libertadoras" e "progressistas". Eu não estava formando "sujeitos críticos e reflexivos". Nenhum desses jargões pedagógicos é capaz de estabelecer qualquer relação com as experiências que vivi nas escolas nas quais 
trabalhei. Na verdade, a cada vez que era obrigado a relembrar algum desses nobres ideais, eles apenas tornavam mais profunda a minha sensação de fracasso como professor, elevando meu sofrimento ao quadrado. Mesmo efeito provocado pelas múltiplas acusações que um certo senso comum faz recair sobre os professores: despreparo, falta de vontade, preguiça ou doutrinação ideológica. Todas tão despropositadas que ganham ares de agressões gratuitas.

Se há uma tonalidade afetiva capaz de marcar minha experiência docente, esta é o desamparo. A derrelição. O abandono. Tão logo adentramos uma sala de aula, os fundamentos nos abandonam. Estamos apenas ali, lançados diante do outro, dos muitos outros singulares que nos acolhem e rejeitam de múltiplas maneiras. Estamos apenas ali, suspensos sobre o abismo: não temos o amparo da direção, nem do governo, nem do “currículo mínimo", nem do conteúdo que supostamente por diversas boas razões deveríamos ensinar, nem da nossa formação acadêmica, nem dos nossos amigos, nem dos nossos familiares... todo amparo nos é subitamente retirado e nos vemos entregues ao desconhecido e ao imprevisível. Nesse momento somos destituídos de tudo aquilo que a modernidade afirmou que temos de mais próprio: não somos mais sujeitos racionais, conscientes e autônomos. Não estamos "no controle". Não somos nenhuma unidade substancial, individual, fechada sobre si mesma. Pelo contrário: a situação é de vulnerabilidade e abertura involuntária ao outro.

\section{Notas sobre a vulnerabilidade humana}

No livro $O$ ocultamento do humano, Martha Nussbaum desenvolve um caminho de reflexão que apresenta a condição humana como permanentemente atravessada por uma tensão irresolvível entre vulnerabilidade e autossuficiência. Ela nos convida a pensar o "amplo papel que os vínculos com aspectos nada seguros do nosso mundo - outras pessoas, os bens materiais de que precisamos, condições políticas e sociais - desempenham em nossa vida emocional", bem como o "amplo papel que 
emoções tais como medo, pesar e raiva desempenham nas trajetórias das vidas humanas, as vidas de animais vulneráveis num mundo de eventos significativos que não controlamos completamente" (NUSSBAUM, 2004, p. 7).

Nossa existência não apenas depende, como é mesmo constituída pela interação de múltiplas e diversas circunstâncias. Existindo, somos atravessados e constituídos por relações - com muitas outras pessoas, muitos outros seres vivos, muitas outras coisas, bens materiais, condições políticas e sociais - que vêm ao nosso encontro, nos marcam, nos afetam, nos carregam consigo por diversos caminhos, sem que tenhamos controle sobre esses processos.

Não por acaso, Freud faz do desamparo o traço fundamental da condição humana. Um traço biológico, que permanece atuante na constituição das neuroses, é "a longa fase de desamparo e dependência do bebê humano" (FREUD, 2014, p. 47). E prossegue afirmando que "A existência intrauterina do ser humano mostra-se relativamente breve, comparada à da maioria dos animais; ele é trazido ao mundo menos 'pronto' do que eles" (FREUD, 2014, p. 47). Os demais animais parecem poder contar com uma programação biológica verdadeiramente eficiente, dotando-os de instintos capazes de lhes garantir, desde muito cedo, um pendor natural para encontrar abrigos e alimentos apropriados. Já o pequeno humano nasce inteiramente incapaz. Entregue à própria sorte, não tardaria a sucumbir. Com ele a natureza parece ter falhado. Embora a programação biológica esteja presente - mais presente do que gostaríamos de admitir -, ela se mostra totalmente ineficiente para guiá-lo por caminhos seguros em busca de proteção e nutrição. Um divórcio entre necessidades instintivas e capacidades motoras que só será superado após anos de estímulos, tentativas e erros, faz com que o mais novo exemplar desta espécie encontre, a cada vez, como condição original, o mais puro desamparo.

Se chega a sobreviver, é porque alguns membros mais maduros da espécie despenderam penosas quantidades de tempo e energia para mantêlo vivo e minimamente saudável - e nos atemos ao plano meramente 
factual dessa afirmação, sem acrescentar a ela qualquer especulação idealista acerca de "instintos maternos" ou configurações ideais de “família". Não é digno de espanto que esses primeiros humanos maduros que lhes satisfizeram as necessidades instintuais mais básicas, garantindo condições mínimas de proteção e alimentação - sejam também os primeiros alvos das suas projeções psíquicas de amor e poder. Projeções que tardarão mais, ou menos, a sofrer rachaduras ou mesmo a serem estilhaçadas pela frustrante compreensão de que estes primeiros referenciais humanos certamente não dispõem de todo o poder e, possivelmente, nem de todo o amor que neles projetamos.

Mesmo crescidos, quando um longo processo de adestramento deu por concluída a difícil tarefa de conciliar faculdades motoras e necessidades instintuais - cujo acordo só pode então ser perturbado por patologias ou substâncias às quais recorremos para a quase inevitável dose de intoxicação que a vida adulta demanda - permanecemos expostos à virulência de eventos traumáticos de todos os tipos, que vêm desavisadamente nos atirar novamente naquela tão familiar - porém sempre tão estranha - condição fundamental de desamparo.

Existem os elementos, que parecem zombar de toda tentativa de coação humana; a terra, que treme, se abre e soterra o que é humano ou obra do homem; a água, que tudo inunda e afoga ao sublevar-se; a tempestade, que tudo varre para longe; há as doenças, que há pouco tempo descobrimos serem ataques de outros seres vivos; e, por fim, o doloroso enigma da morte, para a qual até agora não se achou e provavelmente não se achará remédio. Com essas forças a natureza se ergue contra nós, majestosa, cruel, implacável, sempre nos recordando nossa fraqueza e desvalia, que pensávamos haver superado mediante o trabalho da civilização (FREUD, 2014b, p. 115).

Esse mesmo "trabalho da civilização", que nos protege em alguma medida das forças da natureza, nos "impõe certo grau de privação", enquanto "as 
demais pessoas" nos proporcionam "alguma medida de sofrimento, apesar dos preceitos da cultura, ou por causa das imperfeições dela" (FREUD, 2014b, p. 115).

Eventos traumáticos sobrevindos das mais diversas direções, provocam uma quebra da sensação de estabilidade, de continuidade, bem como do horizonte de significações mais ou menos cristalizadas que nos faz sentir que temos uma rotina cotidiana e que pertencemos, de fato, a um "mundo". É o que o filósofo Frédéric Schiffter chama de acosmismo:

Quando, então, a realidade familiar muda bruscamente de tom; quando o "artifício" que parece moldá-la, como uma providência, é quebrado; quando o corpo afrouxa, os elementos se conturbam e os outros se mostram hostis e se embriagam de matança, dizemos, então, que "o mundo desmorona" descobrindo que isso que desmorona não constituía um mundo, nem fazia parte de um mundo. O que desmorona nada mais é do que a ilusão "cósmica" por meio da qual representávamos a natureza das coisas. Damo-nos conta de que não se tratava de aí não haver nada, mas que aquilo que havia não era nada de pensável como mundo. Pois um mundo, aquilo que os gregos chamavam de kosmos e que os romanos traduziram como mundus, supõe uma ordem, uma arquitetura, uma harmonia e, portanto, uma regularidade, uma estabilidade, uma consistência de tal modo que todo esse ordenamento responderia ao desejo de uma finalidade: o mundo aí estaria para os humanos. Ora, a experiência dolorosa da perda revela uma verdade cruel: a vida humana é só um fenômeno entre outros destinado ao acaso e à morte, ou seja, ao khaos. (...) Tudo se passa como se, ao perder um filho, um amor, um amigo, o trabalho, a saúde, a terra, etc., fôssemos arrancados da quimérica organização do mundo, no seio do qual imaginávamos levar uma existência sensata e digna de humanidade, e lançados na confusão original - exceto que jamais houve outra 
realidade se não esse não-mundo (SCHIFFTER, 2012, pp. 142-143)

Marcados pela experiência incontornável do desamparo, que parece nos remeter de alguma maneira ao desamparo da primeira infância, não é de admirar que tenhamos deslocado aquelas primeiras projeções de amor e, especialmente, de poder, das figuras ideais dos nossos primeiros cuidadores, para entidades metafísicas e sobrenaturais supostamente dotadas do poder absoluto de nos proteger definitivamente do desamparo e de prover a satisfação de todos os nossos desejos e necessidades. Mas é também a marca indelével do desamparo que reencontramos nas mais diversas experiências da aventura humana sobre a Terra. A busca de proteção mútua construiu comunidades, sociedades e civilizações. O interesse em desenvolver e aperfeiçoar técnicas capazes de dobrar em alguma medida o furor desenfreado da natureza, produzindo ferramentas que, por um lado, nos garantem alguma segurança, por outro, algum conforto, está na base da nossa incansável dedicação à investigação científica e ao progresso tecnológico. $\mathrm{E}$ em todos os tempos nunca abandonamos o gosto pelas artes, seja em busca de consolo, catarse ou mera expressão das nossas dores e fraquezas imiscuídas àquela dose de fantasia que as torna, por um lado, ainda mais intensas, por outro, mais suportáveis.

Aquele que se interessa em perscrutar os labirínticos caminhos da vida humana em todos os tempos, talvez acabe por se deparar com a onipresença de dois elementos que parecem marcar com a mesma intensidade nossos empreendimentos existenciais: a experiência incurável do desamparo e a tentativa de fugir do desamparo com o recurso a variadas e sempre renovadas projeções de invulnerabilidade e onipotência. É o que ocorre com as religiões, e com especial clareza naquelas que encontraram em Deus um pai onipotente capaz de nos livrar de todo o mal e de satisfazer todos os nossos desejos e necessidades - ao menos desde que nos comprometamos a seguir os mandamentos a nós transmitidos por seus representantes terrenos. Na vida social, essas projeções de poder absoluto, inicialmente dirigidas aos primeiros cuidadores, se deslocam para funções 
diversas "como juízes, mestres, médicos, padres, policiais..." (MAGNO, 2009, p. 125), além, é claro, daqueles com quem nos envolvemos em relacionamentos amorosos e nos quais projetamos aquelas mesmas exigências de proteção e satisfação que na primeira infância estiveram concentradas em nossos primeiros cuidadores - nos sentindo em geral no direito de nos zangarmos com eles quando insistem em não corresponder ao ideal que neles projetamos. Isso para não mencionar os líderes políticos que, apresentando-se como legítimos representantes do poder absoluto, prometem, como bons salvadores da pátria, resolver todos os nossos problemas e satisfazer todos os nossos desejos e necessidades, garantindo que irão nos proporcionar um estado maximal de ordem, paz, segurança, estabilidade e felicidade (seria cômico, não fosse o fato de parecermos sempre dispostos a embarcar em seus projetos invariavelmente autoritários e violentos, abrindo mão do pouco de liberdade que nos cabe e submetendo tantas pessoas rotuladas como "inimigas do regime" aos mais terríveis castigos, encantados pelo sonho impossível da onipotência e da invulnerabilidade). E mesmo a lida tecnocientífica, apesar de seus ares sempre mais frios e moderados, pode vir acompanhada do sonho baconiano de uma Nova Atlântida, na qual um fantástico progresso tecnocientífico é capaz de nos garantir um estado de perfeita ordem, estabilidade, conforto e segurança.

É também o desamparo e seu aparentemente inevitável avesso, esse ímpeto de fugirmos do desamparo através de projeções ideais de onipotência e invulnerabilidade, que encontramos na base das definições de "humano" formuladas pela tradição metafísica ocidental, ao menos desde Platão. É justamente esse movimento de negação da nossa condição fundamental de desamparo pela projeção de um ideal de humano invulnerável, que dá título ao livro supramencionado de Martha Nussbaum: "a sobreposição da onipotência sobre as vulnerabilidades intrínsecas ao humano é o que a autora denomina de 'o ocultamento do humano"” (CENCI; CASAGRANDA, 2016, p. 481).

\section{Ocultamento do humano}


Tenha-se ou não consciência disso, todo projeto, bem como todo processo educacional, tem como fundamento - assumido ou velado - uma determinada compreensão do "ser" do humano. Numa formulação quase heideggeriana, poderíamos dizer que há uma espécie de "précompreensão" do ser do humano, isto é, uma determinada concepção sobre "o que é" o humano e quais as suas disposições fundamentais (HEIDEGGER, 1999), guiando explícita ou secretamente todos os modos de se fazer e pensar a educação. Afinal, é uma tal concepção que pode, a cada vez, (pré) determinar o que se deve tentar transmitir a um humanoaluno, como se deve conduzir um tal processo e o que se pretende com ele.

Por isso, Lílian do Valle não cessa de interpelar todos os envolvidos com educação, especialmente aqueles que se dedicam aos desafios da Filosofia da Educação, quanto à necessidade de trazermos ao primeiro plano de nossas investigações a reflexão sobre as "bases antropológicas" (DO VALLE, 2003, p. 14) da Educação. Isto é: os "modelos antropológicos", as concepções, compreensões e definições de "humano" que, saibamos ou não, "têm reflexos bastante claros sobre as formas correntes de se considerar o professor, o currículo, a história, as leis e seu caráter instituinte, as teorias e métodos educativos e, é claro, o aluno" (DO VALLE, 2003, p. 13).

A metafísica tradicional ocidental, ao menos desde Platão, contribuiu decisivamente para a construção de uma imagem de "humano" cujo traço mais característico é a postulação de uma instância imaterial que, situada num nível (ontológico, epistemológico e ético) hierarquicamente superior a tudo o que é relacionável ao âmbito "corporal", assume a posição privilegiada de núcleo essencial do "ser" humano. Se é preciso ter cuidado com as generalizações, essa dificilmente nos conduz ao erro: a postulação de uma essência imaterial parece ser a base comum com a qual os diversos contextos sócio-históricos do ocidente moldarão imagens ideais do "humano":

Na história do pensamento ocidental, as tentativas de definição do humano conduziram quase que invariavelmente à postulação de uma 
excepcionalidade raramente contestada, que, garantida por uma dimensão (propriedade, faculdade, substância) entre todos os viventes somente própria aos humanos, foi denominada, conforme o contexto, de psique, de anima, de espírito, de consciência, de mente, de razão. (DO VALLE, 2014, pp. 500-501)

Fazer da essência humana uma "propriedade", "faculdade" ou "substância" imaterial corresponde muito bem aos anseios de invulnerabilidade de um ser que é obrigado a deparar-se, desde muito cedo - e depois disso com alguma frequência - com sua ineliminável condição de desamparo. Uma essência imaterial, chame-se ela alma, espírito, mente ou como for, traz consigo promessas - raramente cumpridas - de unidade, identidade, estabilidade, permanência e, talvez principalmente: a promessa de uma inabalável imperturbabilidade pelas circunstâncias (físicas, biológicas, sociais, políticas, econômicas etc.) que compõem uma determinada configuração contextual. Uma essência imaterial é imune aos muitos encontros com as muitas outras coisas, pessoas e instituições que nos afetam e nos marcam - comodamente tomados, então, como meramente "acidentais". Uma essência imaterial traz consigo o conforto da promessa de permanecer a mesma, aconteça o que acontecer, imune ao desenrolar - por vezes mais intenso e sofrido do que gostaríamos - das diversas circunstâncias que compõem nosso contexto existencial. Assim, alimenta-se a ilusão de que

independentemente de quanto os seres humanos sejam vulneráveis e sujeitos ao acaso, se diferenciam de outros seres em um aspecto fundamental, a saber, a razão ou a alma. Platão, no Fedon (1993, p. 627, 80b), afirma que essa é algo puramente ativo, pois, entre outros atributos, é divina, imortal, inteligível, indissolúvel e invariável. Como constata Nussbaum, Platão, sobretudo nos diálogos da fase intermediária, teria visto tão claramente os problemas da vulnerabilidade humana que somente aceitaria para essa uma solução radical, uma busca filosófica de 
uma vida boa e autossuficiente. A razão poderia, pois, nos governar, salvando-nos de viver à mercê do acaso. (CENCI; CASAGRANDA, 2016, p. 486)

A tradição que, ao menos no que diz respeito às influências filosóficas, tem em Platão um de seus pais fundadores, passa por um longo período de maturação durante a idade média cristã. Baseada na mortificação do corpo - e de tudo aquilo que se pode associar ao corpo - a tradição cristã acrescentou milênios de escavação à fenda platônica, produzindo um verdadeiro abismo entre corpo e alma.

O desprezo e a mortificação da carne estão no cerne da religião que fez de um instrumento de tortura romano - a cruz - o seu símbolo-mor. Jesus Cristo, o filho de Deus, veio ao mundo do ventre de uma virgem e o seu corpo, embora humano na fome e na dor, jamais foi tocado pela mácula do desejo. (GIANNETTI, 2016, § 96)

Nietzsche não cessou de apontar, nas talvez mais ácidas - e precisas - críticas à "moral cristã" até hoje já tecidas, o quanto o cristianismo, em seu caminho para a institucionalização - e, uma vez institucionalizado, para a insaciável concentração e expansão de poder promoveu a sistemática demonização dos desejos como forma de dominação. Demonização que, provavelmente não por acaso, elegeu como alvos privilegiados justamente aqueles desejos que Freud mais tarde admitiria como os "mais básicos" no psiquismo humano: aqueles que podem ser genericamente reunidos sob o signo de Eros e de Tânatos, isto é, os desejos e fantasias sexuais e os desejos e fantasias agressivos.

A insegurança e o desamparo, como se viu, foram motivações para a criação de um modelo de pensamento que apostava mais no mundo abstrato das ideias do que no mundo corpóreo dos cinco sentidos. O desprezo ao corpo pelo cristianismo representa a supremacia de um modelo de subjetividade que 
transformou boa parte das pulsões, não só em erros, como também em pecados. (FERRAREZE; FONSECA, 2018, pp. 298-299)

Transformando as pulsões mais corriqueiras em "pecados", o cristianismo institucionalizado inventou uma doença - que convenientemente se podia encontrar em todos os humanos - para então se apresentar como único detentor do "remédio": o conjunto de "penitências" necessárias para a "salvação da alma" - dinâmica que Nietzsche apelidou de "folie circulaire" [loucura circular] (NIETZSCHE, 2008, § 68). Permanecem ainda desconhecidas as mais sutis implicações dessa milenar educação baseada no desprezo do corpo e demonização dos desejos mais básicos do psiquismo humano.

Esse longo processo, sob pelo menos quinze séculos de domínio hegemônico do cristianismo, de maturação e lapidação de uma essência imaterial cada vez mais decididamente separada do corpo, prepara o terreno para o advento, na modernidade, daquela imagem ideal de humano que ainda hoje parece vigente como "base antropológica" da educação, a saber: o sujeito racional e consciente. Seja como "substância pensante" capaz de conhecimento "claro e distinto" (DESCARTES, 2001) ou como "aparelho de conhecimento" cuja programação - válida para a totalidade dos seres racionais - consiste nas intuições sensíveis e categorias que prédeterminam as condições de apreensão do mundo dos fenômenos (KANT, 2001), o fato é que é muito difícil ainda hoje nos desembaraçarmos da crença de uma autodeterminação racional e consciente da vontade individual. Não importa o quanto as circunstâncias teimem em demonstrar que não estamos no controle de nossas próprias vidas, seguimos denegando veementemente a "ferida narcísica" trazida por Freud, que, segundo ele mesmo, consiste na compreensão de que "o Eu não é senhor em sua própria casa" (FREUD, 2010, p. 186).

No campo da Educação, uma tal compreensão de humano - como sujeito essencialmente racional e consciente - dá origem àquilo que Lílian do Valle chama de "hipervalorização da dimensão cognitiva" (DO VALLE, 2003, p. 14). Para onde quer que nos voltemos, dentro ou fora da 
academia, na palavra dos "especialistas" ou no discurso do senso comum, seja nas críticas, elogios ou propostas, parece que o centro, o cerne, a espinha da questão educacional é o “aprendizado". As críticas, bem fundamentadas por pesquisas sérias ou despejadas no habitual tom revoltado do senso comum, recaem sempre sobre o "déficit" na aprendizagem. Assim como as propostas - tão bem ou mal fundamentadas quanto as críticas - sempre consistem na apresentação de algum "método" muito inovador ou muito antigo, a ser implementado ou resgatado, para que se possa enfim garantir uma boa aprendizagem. Engrossam o caldo dessas críticas e propostas as falas dos numerosos especialistas - não raramente partes economicamente interessadas na discussão - que parecem ter sempre à mão as mais novas descobertas científicas sobre o melhor funcionamento da "cognição" humana.

Desse privilégio decorre o abandono de qualquer preocupação com a ordem das sensações (a menos que seja para assentá-las como base para o desenvolvimento das funções cognitivas); decorre também a exterioridade com que até hoje se trata do problema da consciência e do pensamento (dados como realidades evidentes); a recusa quase sintomática de apropriação das contribuições mais correntes da psicanálise; a superficialidade de sua reflexão sobre a ética; suas dificuldades em enfrentar os problemas que a noção de natureza ainda introduz, sobretudo quando se trata de pensar a igualdade e a alteridade do ponto de vista da prática educativa. (DO VALLE, 2003, p. 14)

Curiosamente, ao propor um sentido macropolítico préprogramado para a Educação: a formação de "sujeitos-cidadãos" capazes de "decisões deliberadas", de sujeitos "autônomos" capazes de autodeterminação racional e consciente numa sociedade plenamente democrática, Lílian do Valle acaba por reencontrar a mesma imagem ideal de humano que tão bravamente se dedicou a combater: o sujeito racional e consciente típico da modernidade. Talvez, para realmente colocarmos em 
questão as "bases antropológicas" da Educação, precisemos nos abrir ao risco do inesperado, abrindo mão, ao menos em alguma medida, das nossas ilusões de controle e invulnerabilidade.

\section{Suposto saber, suposto poder}

A "redução cognitivista", alçada à posição mais que privilegiada de sentido único da educação, faz parecer que todo o problema da educação se reduz à transmissão eficiente de conteúdos de conhecimento de um sujeito racional e consciente para outro sujeito racional e consciente - a tal "educação bancária” tão criticada por Paulo Freire (FREIRE, 1987). É curioso, no entanto, observar que a "hipervalorizarão da dimensão cognitiva" se fez acompanhar, em todos os tempos, por técnicas bastante concretas de dominação corporal, como denunciaria Foucault. Em nome da "boa aprendizagem" que a dimensão cognitiva exige, os corpos foram sistematicamente reprimidos, domados, moldados para caber no minúsculo espaço de uma cadeira, por uma porção de tempo determinada - sempre sob os olhares atentos de vigilantes e sob a ameaça constante das doloridas ou fatigantes punições.

Não é à toa que em seu Ensaio de uma Pedagogia da Singularidade, Germano Prado coloque lado a lado como princípios fundamentais da maneira mais tradicional de se fazer e pensar a educação, a transmissão (de conteúdos de conhecimento entre sujeitos racionais e consciente) e o controle.

Em todo o processo didático-pedagógico de transmissão e verificação (da transmissão) de conteúdos, os elementos institucionais de controle da escola se fazem presentes. Reproduzindo o que seria a estrutura do saber (científico), a escola o divide em disciplinas e atribui a cada uma o tempo que corresponderia ao seu "valor formativo", medido em função de sua capacidade (presumida) de produzir um "cidadão consciente" e/ou, o que é mais comum e cada vez se tem menos vergonha de confessar, um aluno "preparado para o vestibular" (no nível médio) 
ou um produto pronto para atender às necessidades do mercado de trabalho (nos níveis básico e superior) ou, o que em parte quer dizer o mesmo, o corpo dócil, economicamente rentável e politicamente domado. (PRADO, 2015, pp. 3)

Parafraseando Foucault, Germano Prado destaca o papel da escola como "instituição disciplinar" na forja de corpos dóceis e rentáveis prontos para atender as demandas econômicas de produtividade do capitalismo industrial em plena consolidação no século XIX - corpos cuja "docilidade" corresponde muito bem à infinita demanda de submissão e obediência dos poderes políticos dominantes. A escola seria assim, produto e produtora da sociedade de massas.

Mas, ora, o que se espera do humano-professor numa concepção de educação centrada na transmissão e no controle? Sob a égide das "bases antropológicas" cultivadas pelo ocidente platônico, cristão e moderno, os professores foram sistemática e repetidamente colocados na posição de detentores do saber e do poder - espera-se que sejam, nada mais nada menos que os todo-poderosos detentores do saber ou os sábios detentores do poder. Podemos notar que mesmo as críticas mais frequentes ao chamado "sistema tradicional de ensino", tendem a voltar-se para o professor em tom acusatório, denunciando sua postura de "dono do saber" ou "representante do poder" como um dos principais entraves à construção de uma educação verdadeiramente libertadora. Já para os saudosistas de um ideal de educação tradicional que arriscamos afirmar que nunca existiu, o atual "fracasso" da educação escolar se deve à "falta de saber" de um professor desmotivado e desatualizado e, sobretudo, à "falta de poder", de um professor desautorizado e permissivo - aquele a quem falta o "domínio de turma". Isso para não falar nas aberrações contemporâneas veiculadas pelos delirantes defensores de uma "escola sem partido", que acusam os professores de "doutrinadores", isto é, uma vez mais, aqueles que abusam da sua posição de detentores do poder, para transmitir um determinado saber que possuem. 
Essa imagem ideal de humano-professor detentor do saber e do poder é abastecida pelos desejos e as fantasias de invulnerabilidade muito próprias de um ser marcado pela experiência do desamparo. Projeta-se nos professores - e eles próprios projetam em si mesmos muitas vezes fantasias de um poder e de um saber inflacionados que mascaram a incontornável vulnerabilidade da condição humana, para falar como Nussbaum. Talvez parte do sofrimento docente seja o ter de deparar-se não exatamente com o fracasso de alguns planos específicos, mas com o fracasso existencial de não conseguir corresponder a uma projeção ideal de poder e de saber. Se todas as profissões têm suas adversidades e seus fracassos, no caso dos professores, as projeções ideais podem acabar elevando seu sofrimento ao quadrado, acrescentando uma carga desnecessária sobre os já numerosos desafios da profissão.

\section{“Bases antropológicas" contemporâneas}

Tal formulação pode parecer estranha, mas talvez não haja nada mais difícil do que nos tornarmos contemporâneos de nós mesmos. Tendemos a permanecer aferrolhados a convicções passadas e a formulações antigas herdadas da tradição, provavelmente por permanecermos alimentando a esperança de que elas possam nos garantir alguma segurança e estabilidade em meio ao frenesi circunstancial. No entanto, conforme elas insistem em descumprir o que prometem, tendem a tornar nossas vidas mais sofridas do que uma lida propriamente dita com a insegurança e a instabilidade das circunstâncias atuais.

No primeiro ensaio de "Trópicos Utópicos", Eduardo Giannetti apresenta da seguinte maneira nossa situação contemporânea:

O tempo decanta o passado. O que hoje está patente, ontem mal se entrevia. $\mathrm{O}$ mundo moderno nasceu e evoluiu embalado por três ilusões poderosas: a de que o pensamento científico permitiria gradualmente banir o mistério do mundo e assim elucidar a condição humana e o sentido da vida; a de que o projeto de 
explorar e submeter a natureza ao controle da tecnologia poderia prosseguir indefinidamente sem atiçar o seu contrário - a ameaça de um terrível descontrole das bases naturais da vida; e a de que o avanço do processo civilizatório promoveria o aprimoramento ético e intelectual da humanidade, tornando nossas vidas mais felizes, plenas e dignas de serem vividas. Se é verdade que uma era termina quando as suas ilusões fundadoras estão exauridas, então o veredicto é claro: a era moderna caducou. (GIANNETTI, 2016, § 1)

O desenvolvimento científico não baniu o mistério do mundo, vide as especulações sem fim da física quântica que, mais do que inspirações, tornaram-se quase que referência obrigatória para todo tipo de ficção científica. Por outro lado, o desenvolvimento científico demonstrou com alguma clareza que nossas vidas não têm nenhum sentido metafísico. Trata-se apenas de uma combinação não muito misteriosa de informações genéticas e conjunções de moléculas em sistemas organizados. Cabendonos apenas inventar sentidos provisórios ou celebrar a suposição de um ponto em que ausência de sentido e liberdade se encontram. O progresso tecnológico que revolucionou nossas formas de existência e comunicação não parece ter nos tornado realmente mais felizes - o que nada diz contra este mesmo progresso tecnológico, mas sim contra as expectativas desmedidas que nele projetamos. $\mathrm{O}$ século $\mathrm{XX}$ tratou de deixar claro que o mesmo progresso tecnológico que cura doenças, encurta distâncias e nos proporciona um conforto cotidiano inaudito poderia ser empregado para o extermínio eficiente, repentino ou particularmente cruel de milhões de pessoas. E o século XXI não cessa de nos lembrar que o mesmo progresso tecnológico que nos ajudou a resolver muitas "questões ambientais", transformando recursos naturais em benesses várias, gera tantas outras "questões ambientais" ligadas ao esgotamento desses mesmos recursos. Já o processo civilizatório, diante da ampla e irrestrita disseminação do adoecimento psíquico, parece muito mais próximo da ácida lucidez de um Freud, quando discorre longamente sobre o "mal-estar na civilização" do 
que da confiança iluminista num progresso ilimitado capaz de nos fazer "felizes para sempre". Mesmo nossas conquistas mais básicas em termos de noções mínimas de "boa convivência" hoje são colocadas em questão. Por um lado, os grupos historicamente marginalizados e excluídos dessas mesmas noções então supostamente universais de "boa convivência", nos mostram que elas nunca tiveram a universalidade que pretenderam, aplicando-se razoavelmente bem apenas aos que se enquadravam no padrão identitário dominante - no caso brasileiro, os homens, brancos, cristãos e de posses - e deixando de fora todos os que nele não se enquadravam. Por outro lado, o fascínio de um grande número de pessoas em todas as classes sociais pelo discurso abertamente fascista dos novosvelhos donos do poder, nos faz ver o quanto estivemos iludidos com as promessas modernas de "iluminação" e "progresso".

Assim como a maioria dos ideais modernos, o "sujeito" essencialmente imaterial, racional e consciente parece um modelo inteiramente esgotado para pensarmos o humano. Gostaríamos de elencar, com Stuart Hall em seu clássico texto Nascimento e morte do sujeito moderno, as cinco noções contemporâneas que ao mesmo tempo destroem a concepção moderna de sujeito e lançam novas bases para repensar contemporaneamente o ser humano.

Em primeiro lugar, Hall cita a obra de Marx, ao destacar que os humanos "podiam agir apenas com base em condições históricas criadas por outros e sob as quais nasceram" (HALL, 2006, pp. 34-35). Segundo Marx, não é uma essência racional e consciente que permite ao humano se autodeterminar a seu bel-prazer, posto que estamos sempre condicionados por uma realidade material concreta que determina nosso ser, nosso pensar e nosso agir.

O segundo ponto é a obra de Freud e a descoberta decisiva de que nossas ações são determinadas por processos inconscientes. Com Freud emerge a imagem de um humano essencialmente desejante, descentrado e efeito parcial de múltiplas e complexas composições e conflitos entre pulsões, fantasias e repressões. 
A teoria de Freud de que nossas identidades, nossa sexualidade e a estrutura de nossos desejos são formadas com base em processos psíquicos e simbólicos do inconsciente, que funciona de acordo com uma "lógica" muito diferente daquela da Razão, arrasa com o conceito do sujeito cognoscente e racional provido de uma identidade fixa e unificada. (HALL, 2006, p. 36)

O terceiro "descentramento" na moderna noção de sujeito estaria associado ao trabalho do linguista Ferdinand Saussure. Suas investigações problematizam sobremaneira a noção de um "sujeito" estabelecido como centro de comando da linguagem, autoridade reinante a quem se deve atribuir integralmente a autoria da fala.

Saussure argumentava que nós não somos, em nenhum sentido, os "autores" das afirmações que fazemos ou dos significados que expressamos na língua. Nós podemos utilizar a língua para produzir significados apenas nos posicionando no interior das regras da língua e dos sistemas de significado da nossa cultura. A língua é um sistema social e não um sistema individual. Ela preexiste a nós. Não podemos, em qualquer sentido simples, ser seus autores. Falar uma língua não significa apenas expressar nossos pensamentos mais interiores e originais; significa também ativar a imensa gama de significados que já estão embutidos em nossa língua e em nossos sistemas culturais. (HALL, 2006, p. 40)

O "quarto descentramento" apontado por Hall já foi por nós mencionado: trata-se do acompanhamento genealógico do processo histórico que termina por forjar um sujeito individual economicamente rentável e politicamente dócil. Assim, o "humano" não é uma realidade eterna imutável, nem dispõe de uma essência imaterial universal, mas é moldado e configurado de uma determinada maneira por técnicas muito 
concretas de disciplinação corporal, correspondendo a exigências de um determinado contex to histórico. (HALL, 2006, pp. 41-43)

Por fim, o "quinto descentramento" diz respeito aos também já mencionados movimentos de contestação e lutas por visibilidade, direitos e participação social e política por parte dos grupos historicamente marginalizados, excluídos e violentados de múltiplas maneiras físicas e simbólicas por não corresponderem ao padrão identitário ideal dominante na sociedade ocidental - masculino, branco, cristão e de posses. Os movimentos das chamadas "minorias" - mulheres, negros, gays etc., minorias em participação sociopolítica, mas não em quantidade - vêm mostrar que a suposição de uma essência humana universal acabou mascarando sob a fachada de um "nós, humanos", as diversas violências contra as muitas pessoas singularmente divergentes dessa essência que, por mais que se pretendesse abstrata e universal, tinha uma "cara" bastante concreta e particular - a "cara" dos grupos sociais dominantes. (HALL, 2006, pp. 43-46)

Há ainda todo um movimento de pensamento existencialista ao longo do século XX com expressões tão diversas quanto as de Heidegger, Sartre, Simone de Beauvoir, Hannah Arendt, Ortega y Gasset, que remetem de alguma maneira ao gesto desafiador de Nietzsche em relação à tradição metafísica. Embora tenham elaborado suas reflexões de maneiras muito diferentes, todos compartilham a ideia fundamental de que "a existência precede a essência", isto é, existimos em meio a muitas circunstâncias de todos os tipos - sociais, políticas, culturais, fisiológicas, emocionais, interpessoais etc. - que se entrelaçam singularmente em nós, construindo pouco a pouco para nós um "ser". É o movimento das circunstâncias que vai nos tornando a cada momento o que somos.

Que significa dizer que a existência precede a essência? Significa que o humano primeiro existe, se encontra, surge no mundo, e que se define depois. O humano, tal como o existencialista o concebe, se não é definível, é porque de início ele não é nada. Ele só 
será em seguida, e será como se tiver feito. (SARTRE, s/d, 619-620)

Na bela formulação de Ortega y Gasset:

De imediato e sem saber como nem por quê, sem anúncio prévio, o homem se descobre e surpreende tendo de "ser" num âmbito impremeditado, imprevisto, neste de agora, numa conjuntura de circunstâncias. determinadíssimas (...) Chamemos provisoriamente, para facilitar a compreensão desse âmbito impremeditado e imprevisto, essa circunstância determinadíssima na qual, ao viver, nos encontramos sempre, de mundo. Pois bem, esse mundo no qual tenho de ser ao viver me permite escolher, dentro dele, estar nesse lugar ou noutro, mas a ninguém é dado escolher o mundo em que se vive: é sempre este, este de agora. Não podemos escolher o século, nem o dia ou a data em que vamos viver, nem o universo em que vamos nos mover. $\mathrm{O}$ viver ou o ser vivo, que são a mesma coisa, o ser homem, não admite preparação nem ensaio prévio. A vida nos é disparada a queima-roupa. (ORTEGA Y GASSET, 2017, 63)

É uma tal compreensão que faz Hannah Arendt afirmar repetidamente que "os homens, e não O Homem, vivem na Terra e habitam o mundo" (ARENDT, 2010, pp. 8-9), destacando que não é uma essência eterna que pré-determina nosso ser, mas que cada um de nós é resultado do entrelaçamento único de múltiplas e variadíssimas circunstâncias. Em outras palavras: não é um ideal de humano que circula por aí em meio a ocupações cotidianas e relações interpessoais. São pessoas encarnadas, que sentem dores e experimentam prazeres, que vibram e se frustram, pessoas constituídas por circunstâncias determinadas que as fazem absolutamente singulares.

Já faz tempo estão lançadas as indicações contemporâneas para repensarmos as "bases antropológicas" da vida e da educação. Elas nos 
colocam diante de um humano encarnado, descentrado, múltiplo, aberto aos inevitáveis encontros com múltiplas circunstâncias, coisas, pessoas e instituições que o atravessam, que o constituem, que o marcam, que o afetam e o carregam consigo por caminhos inesperados. Um humano que "a priori" tem apenas uma programação biológica que, como podemos verificar no completo desamparo infantil, em nosso caso, não é fechada nem definitiva. Um humano, portanto, construído "a posteriori" pelo entrelaçamento complexo das muitas circunstâncias e relações de todos os tipos que tornam cada um de nós uma configuração absolutamente singular sempre inacabada e sempre em movimento.

Mas, assumir uma tal condição humana, envolve assumir uma condição de incurável desamparo e incontornável vulnerabilidade.

Claro que o ser humano se verá então numa situação difícil, terá de admitir seu completo desamparo, sua irrelevância na engrenagem do universo, já não será o coração da Criação o objeto da carinhosa atenção de uma Providência bondosa. Estará na mesma situação de um filho que deixou a casa do pai, que era aquecida e confortável. Mas não é inevitável que o infantilismo seja superado? O ser humano não pode permanecer eternamente criança, tem de finalmente sair ao encontro da "vida hostil". Podemos chamar a isso "educação para a realidade"; ainda preciso the dizer que o único objetivo deste trabalho é chamar a atenção para a necessidade de dar esse passo? (FREUD, 2014, p. 134)

Talvez por isso resistamos tanto a uma "educação para a realidade", preferindo muitas vezes seguir imaginando um humano ideal, invulnerável e autossuficiente.

\section{Desamparo, vulnerabilidade, micropolítica}

Sob novas "bases antropológicas" torna-se possível, se não mesmo necessário, repensar a formação e as expectativas em relação à atuação do 
humano-professor. Recapitulemos as principais diferenças entre as possibilidades de compreensão do humano que a contemporaneidade nos proporciona em relação à imagem ideal de humano que a tradição ocidental nos legou:

1. Enquanto uma essência imaterial garante a preservação de uma unidade substancial a priori, indivisível (eis a raiz da própria palavra "indivíduo") e inabalável, a contemporaneidade nos permite pensar o humano como multiplicidade de relações, encontros, afetos, pulsões, circunstâncias. Isso se deve principalmente a uma tentativa de subverter milênios de "desprezo do corpo", trazendo ao primeiro plano a dimensão corporal, afetiva e desejante da humanidade, o que nos leva ao ponto dois:

2. Em lugar de um humano essencialmente definido por uma instância imaterial - alma, espírito, mente, consciência, razão -, temos um humano encarnado num corpo afetivo e desejante, atravessado e constituído por pulsões e fantasias que nem controlamos nem compreendemos completamente.

3. Ao invés da simplicidade de uma substância imaterial única, nossa verdadeira singularidade advém do entrecruzamento e entrelaçamento de múltiplas e diversas circunstâncias de todas as ordens biológicas, físicas, sociais, culturais, econômicas, interpessoais, emocionais etc - que se articulam num sistema circunstancial complexo, com padrões de organização e estabilidades provisórios.

4. Em lugar da identidade de uma "alma" ou "espírito" idênticos a si mesmos (na forma do princípio de identidade $\mathrm{A}=\mathrm{A}$ ), encontramos o humano numa situação de verdadeira abertura ao "outro" aos muitos "outros" - as muitas outras circunstâncias, coisas, pessoas e instituições que nos atravessam e nos constituem, que nos marcam e nos afetam.

5. Em lugar da autossuficiência de um "sujeito" imaterial plenamente constituído existente em si e por si mesmo apesar de qualquer circunstância fática na qual se encontre, temos um humano essencialmente relacional e, portanto, vulnerável ao movimento irrefreável das circunstâncias do mundo. 
O que esperar do humano-professor diante de uma tal compreensão do ser humano? Como professores, realmente ocupamos uma posição que envolve saberes e poderes. Não adianta tentar mascarar esse fato com afirmações denegatórias do tipo: "sabemos tanto quanto nossos alunos", "os alunos é que têm o saber" ou "não há hierarquia entre aluno e professor, somos todos iguais". Processos educacionais envolvem saberes, poderes, transmissão de conteúdos e alguma tentativa de controlar as condições de transmissão desse conteúdo.

No entanto, esta certamente não é a única dimensão dos processos educacionais. A educação - como o humano - não se reduz a uma dimensão puramente intelectual. Está em jogo ali uma maranha de afetos, desejos, projeções e relações interafetivas que interferem de fato nas vidas dos envolvidos - professores e alunos. Saberes são importantes. Quanto mais buscamos saberes relativos ao exercício da nossa prática docente, maior nosso repertório para nos virar em meio às circunstâncias sempre singulares de uma determinada aula. Poderes estão em jogo. É importante reconhecermos que há no ensino uma relação de poder, até para nos colocarmos em condições de pensar e repensar seus limites e (im)possibilidades.

O problema é que os modelos de humano-professor que a tradição nos legou apenas projetam sobre o professor um ideal de "saber" e "poder" quase absolutos e, portanto, inatingíveis. Uma compreensão contemporânea do humano-professor traz consigo a exigência - ou ao menos a possibilidade - de incluirmos na formação de professores todo um generoso espaço para o aprendizado do não-saber e do não-poder que envolvem a atividade docente. Colocar em questão as antigas "bases antropológicas" da vida e da educação exige o difícil - porém libertador exercício de nos depararmos com nosso irremediável desamparo, de assumirmos nossa incontornável vulnerabilidade, para enfim nos abrirmos ao risco, à imprevisibilidade, à experimentação, aprendendo a jogar, a cada vez, com as múltiplas e variadas circunstâncias que tornam cada aula - em cada turma, em cada sala, em cada escola, em cada bairro, em cada humor, 
em cada condição física, em cada tempo e cada lugar - absolutamente singular.

Para que possamos assumir nossa contemporânea condição humana - e a contemporânea condição docente que ela traz consigo - é preciso que estejamos dispostos a abrir mão das ilusões de controle e onipotência que temos projetadas sobre nós - pelos outros e por nós mesmos. Isso envolve aceitar que talvez transformações macropolíticas não estejam em nosso poder. Talvez não esteja em nosso poder formar "sujeitos críticos e reflexivos", talvez não esteja em nosso poder "revolucionar" a totalidade da sociedade em qualquer sentido, assim como não estará em nosso poder "conservar" as estruturas estabelecidas na sociedade na contramão do tempo e das circunstâncias. Por outro lado, não é preciso esperar uma "revolução social" para que possamos, só então, usar nossa posição para fazer algo relevante. Há toda uma micropolítica da educação que, cotidianamente, está lançada para cada um de nós como desafio. Ali, nas relações cotidianas, na circulação de afetos, nas discussões que levamos ou não levamos para a sala, nos materiais e obras de arte de todos os tipos que levamos para os alunos, no simples exercício do ouvir e do falar, do ler e do escrever, nos olhares e no tom de voz, nas piadas - feitas ou não feitas -, nos elogios e nos incentivos, há uma micropolítica em movimento. Uma micropolítica que provavelmente não terá nenhum impacto macropolítico, mas que poderá ter um efeito transformador - incontrolável e imprevisível - nas vidas de pessoas singulares.

\section{Referências bibliográficas}

ARENDT, Hannah. A condição humana. Rio de Janeiro: Forense Universitária, 2010

CENCI, Angelo; CASAGRANDA, Edison. A educação para a democracia entre a vulnerabilidade e a autossuficiência humana. Revista Conjectura. Caxias do Sul, v. 21, n. 3, 2016. https://doi.org/10.18226/21784612.v21.n3.02 
DESCARTES, René. Discurso do Método. São Paulo: Martins Fontes, 2001.

DO VALLE, Lílian. Teoria, determinação, complexidade: desafios da reflexão sobre educação. Revista Trabalho Educação e Saúde, 1(2), 2003. https://doi.org/10.1590/S1981-77462003000200002

- Para além do sujeito isolado: modelos antropológicos para pensar a educação. Revista Brasileira de Educação, v. 19, n. 57, 2014. https://doi.org/10.1590/S1413-24782014000200012

FILHO, Paulo Ferrareze; FONSECA, Sarah. Desamparo originário e construção da subjetividade ocidental. Revista Húmus v. 7, n. 23, 2018

FREIRE, Paulo. Pedagogia do Oprimido. Rio de Janeiro: Paz e Terra, 1987

FREUD, Sigmund. Inibição, Sintoma e Angústia (Obras completas, vol. 17). São Paulo: Cia das Letras, 2014

. O Futuro de uma Ilusão (Obras completas, vol. 17). São Paulo: Cia das Letras, 2014b

. Uma dificuldade da Psicanálise (Obras completas, vol. 14). São Paulo: Cia das Letras, 2010

GIANNETTI, Eduardo. Trópicos Utópicos. São Paulo: Cia das Letras, 2016

HALL, Stuart. A identidade cultural na pós-modernidade. Rio de Janeiro: DPeA, 2006

HEIDEGGER, Martin. Introdução à metafísica. Rio de Janeiro: Tempo Brasileiro, 1999 
KANT, Immanuel. Crítica da Razão Pura. Lisboa: Calouste Gulbenkian, 2001

MAGNO, Machado Dias. A Rebelião dos Anjos. Rio de Janeiro: NovaMente, 2009

NIETZSCHE, Friedrich. Ecce Homo. São Paulo: Cia das Letras, 2008

NUSSBAUM, Martha. Hiding from humanity. New Jersey: Princeton, 2014

ORTEGA Y GASSET, José. O homem e os outros. Campinas: Vide Editorial, 2017

PRADO, Germano. Ensaio de uma pedagogia da singularidade. Ciudad de Mexico: Actas del Tercer Congresso de Filosofia de la Educación (ALFE). Vol. 3, 2015

SARTRE, Jean-Paul. O Existencialismo é um Humanismo. In: Antologia de textos Filosóficos. Paraná: Secretaria de Estado de Educação, s/d

SCHIFFTER, Frédéric. Filosofia Sentimental. Rio de Janeiro: Difel, 2012

Data de registro: $20 / 05 / 2020$

Data de aceite: 02/10/2020 